\title{
Growth curve establishment for American Bronze turkeys
} (short communication)

\begin{abstract}
The purpose of this study was to establish the growth curves parameters of American Bronze turkeys. The weekly body weight changes of male and female turkeys were recorded during 11 to 24 weeks of age. The Richards' growth model fitted the turkey weight and age (week) data. Profile analysis was also applied to weight-age data in order to get more detailed information about the differences in the live weights of male and female turkeys in consecutive weeks. Estimates for mature body weight were found as $9720.40 \pm 971.33 \mathrm{~g}$ and higher for males than for females as $6029.96 \pm 316.55 \mathrm{~g}$. Based on Richards' model, male turkeys matured more slowly and it was needed that a more time to reach mature body weight than female turkeys. Results of profile analysis supported those results. Estimates for the absolute growth rate, absolute maturing rate and relative growth rate values were higher for females when compared to males. Male turkeys reached the maximum growth rate at 16.30 weeks of age whereas female ones reached the maximum growth rate at 12.85 weeks of age. Live weights of male and female turkeys, when both reached the maximum growth rate, were $3475.61 \mathrm{~g}$ and 2156.06 g, respectively. Male turkeys reached $80 \%$ of their mature weights at 24 weeks of age, whereas female ones reached $92 \%$ of their mature weight.
\end{abstract}

Key Words: growth curve, body weight, non linear regression, Richards’ function, American Bronce turkey

\section{Zusammenfassung}

Titel der Arbeit: Charakterisierung des Wachstums Amerikanischer Bronzeputen mittels Wachstumskurven (Kurzmitteilung)

Das Ziel der Arbeit war die Charakterisierung des Wachstums Amerikanischer Bronzeputen mittels Wachstumsfunktionen. Während der 11. und 24. Woche wurden wöchentlich die Körpergewichte von 103 männlichen und weiblichen Tieren erfasst. Die Datenbearbeitung erfolgte mittels des Richards Wachstumsmodells. Um die in den einzelnen Wochen sich ergebenden altersabhängigen Gewichtsveränderungen bei den männlichen und weiblichen Tieren genauer beurteilen zu können, wurde die Profilanalyse genutzt. Die Schätzwerte der männlichen Tiere lagen in der 24 . Woche mit 9720,40 $\pm 971,33$ g höher als die der weiblichen mit 6029,96 $\pm 316,55 \mathrm{~g}$. Auf der Basis der Richardsfunktion ergab sich, dass die männlichen bei einer relativ geringeren absoluten Reife und bei der wöchentlichen relativen Wachstumsrate langsamer als die weiblichen Tiere das 24-Wochengewicht erreichen, eine Aussage welche durch die Profilanalyse bestätigt wurde. Bei den männlichen Tieren lag die maximale Wachstumsrate im Alter von 16,3 Wochen, die der weiblichen in der 12,8. Woche. Zu diesem Zeitpunkt wogen die männlichen Tiere 3475,61 g und die weiblichen 2156,06 g. Im Alter von 24 Wochen erreichten die männlichen Tiere 80 \% und die weiblichen Tiere $92 \%$ ihres adulten Körpergewichtes.

Schlüsselwörter: Wachstumskurve, Körpergewicht, Nicht lineare Regression, Richardsfunktion, Amerikanische Bronzepute

\section{Introduction}

Growth is a fundamental property of biological systems and it can be defined as an increase in body size per time unit (SCHULZE et al., 2001; LAWRENCE and FOWLER, 2002). Understanding of the economic importance of various traits such as live weight, weight gain, rate of maturity, age and live weight at which maximal growth phase has led researchers to carry out detailed studies targeting weight-age 
relation. For this reason, different mathematical growth models have been developed (RICHARDS, 1959; LEHMANN, 1977; SAGER, 1982; ZEIDE, 1993; SEEDLAND et al., 1996; MATTHES et al., 1996; MARUYAMA et al., 1998; PISCART et al., 2003). Two important parameters of growth are the genetic potential for growth and the time to reach maturity. When animal growth is described by a growth curve, these parameters can be presented as biologically interpretable constants in a mathematical equation. Animal growth generally follows a sigmoidal pattern (S- shape). For this purpose, the Brody, Richards, Gompertz, logistic, Von Bertalanffy, Weibull, and Morgan-Mercer-Flodin growth models are commonly used to explain animal growth. The Richards and Gompertz models have been shown to give descriptions of growth in species such as cattle, elk, chickens, ostrich, turkey, and emus. The Richards' model is a more flexible and generalized four-parameter function with a variable inflection point that provides a more complete description of growth process in a variety of animal species (VON ROSEN, 1991; GOONEWARDENE et al., 2003). Though there are many studies aiming at evaluating growth models, the number of studies targeting growth models in turkeys (SALOMON et al., 1987; EMMANS, 1989; ANTONY et al., 1991; HURWITZ, 1991; ANDRASSY-BAKA et al., 2003; SZÖKE et al., 2004) is quite limited as compared to other poultry species (HAVENSTEIN et al., 1994; MARUYAMA et al., 1999; AGGREY, 2004).

The main purpose of this study was to estimate the growth curve parameters for American Bronze turkeys in semi-intensive conditions.

\section{Material and Methods}

The data came from a total of 103 American Bronze turkeys with 41 males and 62 females were used in this research. The birds were raised under semi-intensive condition. All the birds were fed with turkey poultry starter diet firstly (from hatch to 7 weeks), then a turkey grower diet (8 to 9 weeks) and a mixture of $1 / 4$ turkey grower diet and ad libitum wheat for 2 weeks following the birds returned from the pasture. The starter and grower diets of the birds included 28\% crude protein, 2900-3000 ME $\mathrm{kcal} / \mathrm{kg}$ and $22 \%$ crude protein, 2800-2900 ME kcal/kg, respectively. Throughout 11 to 24 weeks of age, weekly body weights of male and female turkeys were recorded.

The Richards' growth model was chosen to describe age-weight relation in turkeys, because of Richards' growth model was found more effective than other models such as Gompertz, Logistic, and Von Bertalanffy in the preliminary analysis. In the comparison of effectiveness of the models, $\mathrm{R}^{2}$, residual mean square error (RMSE), asymptotic correlations and Durbin-Watson statistic (DW) were used (LAMARE and MLADENOV, 2000). The Richards' growth model was fitted to the body weight and age data of turkeys, using the NLIN procedure of the SAS software. The Marquardt iterative procedure was used to reduce the residuals and improve the fit (SAS Inc., 1999; BAYRAM et al., 2004). Statistical significance of non-linear model parameters was determined using $95 \%$ asymptotic confidence intervals. The Richard's model defined as $Y_{t}=A\left(1-b e^{-k t}\right)^{m}$

where, A: mature weight when time $(\mathrm{t}) \rightarrow \infty$

b: an integration constant

$\mathrm{k}$ : Coefficient of relative growth or maturing index (where a smaller $\mathrm{k}$ value indicates late maturing, and a larger $\mathrm{k}$ value indicates early maturing) 
m: Shape parameter that determines the time inflection (Ti) and the weight at inflection (Wi)

In this study, based on the parameter estimates obtained by fitting the Richards' function, the following formulas were used to calculate the growth information:

Time Inflection $\left(\mathrm{T}_{\mathrm{i}}\right)=\mathrm{k}^{-1} \ln \mathrm{mb}$, Weight Inflection $\left(\mathrm{W}_{\mathrm{i}}\right)=\mathrm{A}\left(\frac{\mathrm{m}-1}{\mathrm{~m}}\right)^{\mathrm{m}}$, Absolute Growth Rate $(A G R)=\frac{0.5 A m k}{(2 m-1)}$, Absolute Maturing Rate $(A M R)=\frac{0.5 m k}{(2 m-1)}$, Relative Growth Rate $(\mathrm{RGR})=\frac{\mathrm{mk}}{(\mathrm{m}-1)}$, and Degree of Maturity $(\mathrm{DM})=\frac{\mathrm{W}_{\mathrm{t}}}{\mathrm{A}}$ (GOONEWARDENE et al., 2003).

In this study, two-sample profile analysis was also adapted to compare live body weights of male and female turkeys to get more detailed information about sequential weeks’ differences (RECHNER, 1995; MENDEŞ et al., 2005).

\section{Results}

The models with small RMSE, high $\mathrm{R}^{2}$, independent errors (without autocorrelation) and those with asymptotic correlations smaller than 0.95 were preferred among the models such as Gompertz, logistic and von Bertalanffy used in estimation of growth parameters in turkeys. The Richards' growth model fitted the turkey weight and age data very well with $\mathrm{R}^{2} \geq 98.0 \%$. The residual mean square error (RMSE) was highest for the male turkeys, which had a low number of records. All parameter estimates and growth characteristics for turkeys based on Richards' growth model were significant (Table $1, \mathrm{P}<0.05)$. Maturing index $(\mathrm{k})$ value for female turkeys was clearly higher than for males. On the other hand, the value of m parameter of male turkey was 1.03 times higher for male when compared to female. Results of Profile analysis showed that the difference in mean live weights of the turkeys between weeks depends on sex $(\mathrm{P}<0.01$, Table 3). Figure 1 tends to support this conclusion.

Table 1

Parameter estimates and growth characteristics of male and female turkeys data based on the Richards' model (Parameter der Wachstumseigenschaften männlicher und weiblicher Tiere nach dem Richardsmodell)

\begin{tabular}{lcccc}
\hline Parameter $^{1}$ & Male & $95 \%$ CI & Female & $95 \%$ CI \\
\hline$A$ (g) & $9720.40 \pm 971.33$ & $7556.29-11884.49$ & $6029.96 \pm 316.55$ & $5324.41-6735.46$ \\
$B$ & $2.65 \pm 0.76$ & $0.95-4.36$ & $4.25 \pm 1.18$ & $1.61-6.90$ \\
$k$ (per week) & $0.24 \pm 0.076$ & $0.08-0.41$ & $0.39 \pm 0.11$ & $0.14-0.63$ \\
$m$ & $18.83 \pm 0.34$ & $18.07-19.60$ & $18.24 \pm 0.41$ & $17.33-19.16$ \\
$R^{2}$ (\%) & 98.90 & - & 99.84 & - \\
RMSE & 42662.61 & - & 32875.95 & - \\
DW & 2.00856 & - & 1.47474 & - \\
$T i$ (week) & 16.30 & - & 12.85 & - \\
$W i$ (g) & 3475.61 & - & 2156.06 & - \\
AGR (g/week) & 599.13 & - & 604.49 & - \\
AMR (per week) & 0.062 & - & 0.100 & - \\
RGR (g/week) & 0.25 & - & 0.41 & - \\
\hline
\end{tabular}

${ }^{1}$ A: Mature weight when time $(t) \rightarrow \infty$; $b$ : An integration constant; $k$ : Coefficient of relative growth or maturing index; $m$ : A shape parameter that determines the time inflection (Ti) and the weight at inflection (Wi); AGR: Absolute growth rate; AMR: Absolute maturing rate; RGR: Relative growth rate 
It was determined that male turkeys reached $80 \%$ of their mature weights at 24 weeks of age, whereas female ones reached $92 \%$ of their mature weight (Table 2).

Table 2

Descriptive statistics and degree of maturity (\%) (Beschreibende Statistik des Reifegrades)

\begin{tabular}{|c|c|c|c|c|}
\hline \multirow[b]{2}{*}{ Week } & \multicolumn{2}{|c|}{ Male $(n=41)$} & \multicolumn{2}{|c|}{ Female $(n=62)$} \\
\hline & $\bar{X} \pm S_{\bar{X}}(g)$ & $\begin{array}{l}\text { Degree of Maturity } \\
\text { (\%) }\end{array}$ & $\bar{X} \pm S_{\bar{X}}(g)$ & $\begin{array}{l}\text { Degree of Maturity } \\
(\%)\end{array}$ \\
\hline 11 & $2228.0 \pm 42.36$ & 23 & $1847.6 \pm 28.91$ & 31 \\
\hline 12 & $2407.3 \pm 42.13$ & 25 & $1984.7 \pm 27.24$ & 33 \\
\hline 13 & $2711.0 \pm 47.89$ & 28 & $2156.5 \pm 28.61$ & 36 \\
\hline 14 & $3159.8 \pm 58.50$ & 33 & $2472.5 \pm 30.75$ & 41 \\
\hline 15 & $3569.5 \pm 67.11$ & 37 & $2747.6 \pm 32.06$ & 46 \\
\hline 16 & $4007.3 \pm 70.90$ & 41 & $3074.2 \pm 33.90$ & 51 \\
\hline 17 & $4487.8 \pm 76.11$ & 46 & $3435.5 \pm 39.22$ & 57 \\
\hline 18 & $5032.9 \pm 81.43$ & 52 & $3826.6 \pm 42.40$ & 63 \\
\hline 19 & $5434.2 \pm 82.58$ & 56 & $4136.3 \pm 46.49$ & 69 \\
\hline 20 & $6061.0 \pm 90.22$ & 62 & $4536.3 \pm 52.02$ & 75 \\
\hline 21 & $6435.4 \pm 85.66$ & 66 & $4777.4 \pm 54.47$ & 79 \\
\hline 22 & $6797.6 \pm 89.55$ & 70 & $4963.7 \pm 57.60$ & 82 \\
\hline 23 & $7320.7 \pm 96.23$ & 75 & $5297.6 \pm 60.56$ & 88 \\
\hline 24 & $7754.9 \pm 100.14$ & 80 & $5541.1 \pm 64.80$ & 92 \\
\hline
\end{tabular}

Table 3

Differences among the sex for different weeks (Differenz zwischen den Geschlechtern in unterschiedlichen Wochen)

\begin{tabular}{cccc}
\hline Sequential week difference & Male & Female & $\mathrm{P}$ \\
\hline $1-2$ & 179.3 & 137.1 & 0.046 \\
$2-3$ & 303.7 & 171.8 & 0.000 \\
$3-4$ & 448.8 & 316.1 & 0.000 \\
$4-5$ & 409.7 & 275.0 & 0.000 \\
$5-6$ & 437.8 & 326.6 & 0.000 \\
$6-7$ & 480.5 & 361.3 & 0.000 \\
$7-8$ & 545.1 & 391.1 & 0.000 \\
$8-9$ & 401.3 & 309.7 & 0.000 \\
$9-10$ & 626.8 & 400.0 & 0.000 \\
$10-11$ & 374.4 & 241.1 & 0.000 \\
$11-12$ & 362.2 & 186.3 & 0.000 \\
$12-13$ & 523.1 & 333.9 & 0.000 \\
$13-14$ & 434.2 & 243.5 & 0.000 \\
\hline
\end{tabular}

Table 4

Asymptotic correlation coefficients between estimated parameters for male and female (Asymptotische Korrelationskoeffizienten zwischen Schätzparametern bei männlichen und weiblichen Tieren)

\begin{tabular}{lcccc}
\hline Sex & & \multicolumn{3}{c}{ Male (Female) } \\
& Maturing Weight (A) & Integration Constant (b) & Maturin Index (k) & Shape Parameter (m) \\
\hline A & $1.00(1.00)$ & $-0.96(-0.93)$ & $-0.98(-0.95)$ & $0.21(-0.51)$ \\
b & $-0.96(-0.93)$ & $1.00(1.00)$ & $0.99(0.99)$ & $0.06(0.78)$ \\
k & $-0.98(-0.95)$ & $0.99(0.99)$ & $1.00(1.00)$ & $-0.02(0.72)$ \\
m & $0.21(-0.51)$ & $0.06(0.78)$ & $-0.02(0.72)$ & $1.00(1.00)$ \\
\hline
\end{tabular}




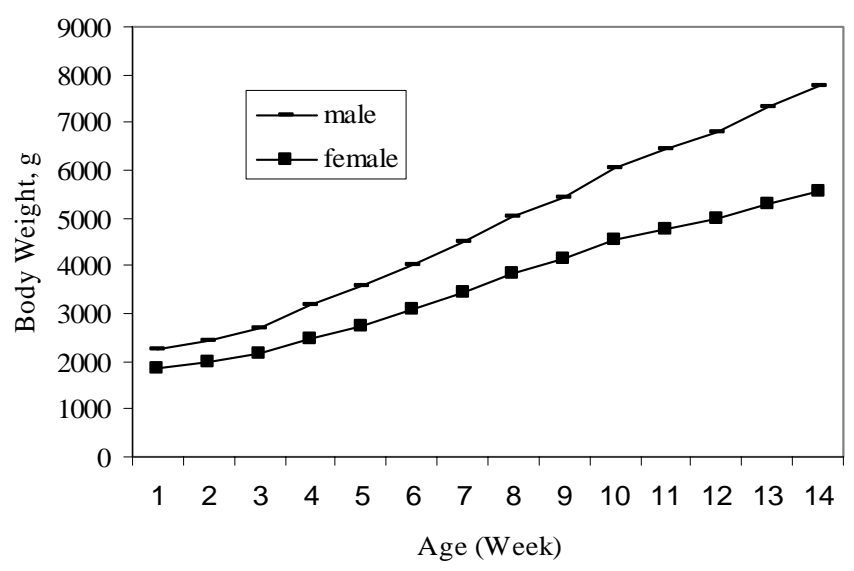

Fig. 1: Growth curves for male and female turkeys (Wachstumskurven für männliche und weibliche Puten)

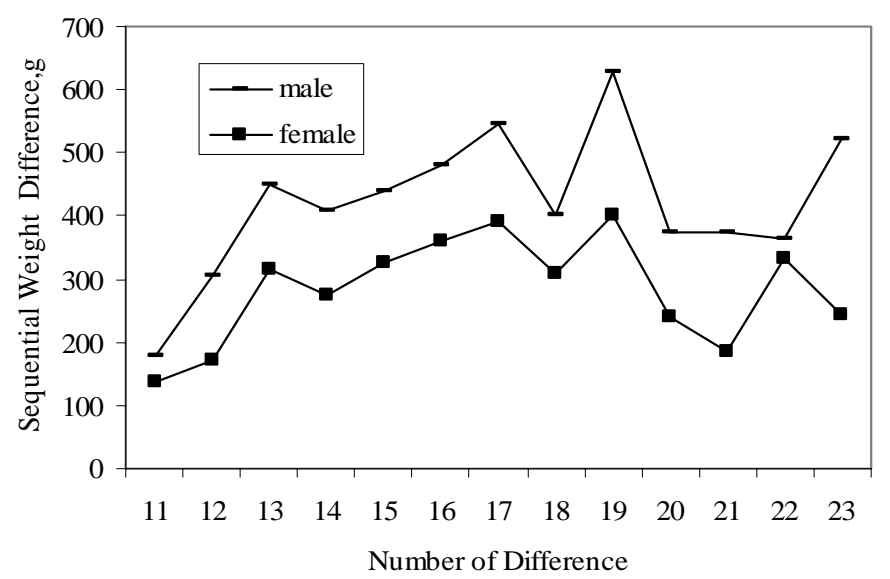

Fig. 2: Sequential weight differences by weeks in both sexes (Sequenzielle Gewichtsunterschiede nach Wochen bei beiden Geschlechtern)

\section{Discussion}

Based on Richards' model, it was determined that male turkeys matured more slowly and it took a more time to reach mature body weight than female turkeys. Although the hatching weights of females were lower than those of males, "b" parameter that is the ratio of total weight gain after hatching to mature weight was found higher (BAYRAM et al., 2004). The velocity of growth was found as maximum at 16.30 week of age when the male turkeys were $3475.61 \mathrm{~g}$ and was found as maximum at 12.85 week of age when female turkeys were $2156.06 \mathrm{~g}$. It is worth noting that the age at which male turkeys reached maximum growth rate was higher than the age at which female turkeys reached maximum growth rate. The AGR was found as $599.13 \mathrm{~g} /$ week for males and $604.49 \mathrm{~g} /$ week for females. During 11 to 24 weeks of age, the mean weekly weight gain in males and females were found as $553 \mathrm{~g}$ and $395 \mathrm{~g}$, respectively. In males and females, the weight gain was found as $667 \mathrm{~g} /$ week and $724.36 \mathrm{~g} /$ week until the time that the score whenever the velocity of growth was achieved maximum level. The gain accelerated to $466 \mathrm{~g} /$ week and $335.76 \mathrm{~g}$ /week after reached that value. It was observed that female turkeys had higher weight gains when compared to males before the time that the score whenever the velocity of growth was found as maximum, while male turkeys had higher weight gains after that score. Table 3, Figure 1 and Figure 2 
were created to demonstrate the differences in the live weights of male and female turkeys in consecutive weeks. It was apparent that the differences in the live weights of turkeys in consecutive weeks varied according to sex, and these differences are at the favor of male turkeys. These findings are similar to the findings of (MENDES et al., 2005).

According to the results of either preliminary or decisive analyses it was revealed that Richards' growth model fitted-very well weight and age for American bronze turkeys.

\section{AGGREY, S.E.:}

\section{References}

Modelling the effect of nutritional status on pre-asymptotic and relative growth rates in a random-bred chicken population. J. Anim. Breed. Genet. 121 (2004) 4, 260-268

ANDRASSY-BAKA, G.; ROMVARI, R.; LANGLEY-EVANS, S.C.; BUTTERY, P.J.:

Comparative study of the body composition of different turkey genotypes by means of CT. Arch. Tierz., Dummerstorf 46 (2003) 3, 285-292

ANTONY, N.B.; EMMERSON, D.A.; NESTOR, K.E.; BACON, W.L.:

Comparison of growth curves of weight selected populations of turkeys, quail and chickens. Poult. Sci., 70 (1991), 13-19

BAYRAM, B.; AKBULUT, O.; YANAR, M.; TUZEMEN, N.:

Analysis of growth characteristics using the Richards model in female Brown Swiss and Holstein Friesian cattle. Turk. J. Vet. Anim. Sci., 28 (2004), 201-208

EMMANS, G.C.:

The growth of turkeys. In recent advances in turkey science (ed. C. NIXEY and T.C. GREY). Butterworths, London. (1989), pp. 135-166

GOONEWARDENE, L.A.; WANG, Z.; OKINE, E.; ZUIDHOF, M.J.; DUNK, E.; ONDERKA, D.: Comparative growth characteristics of Emus (Dromaius novaehollandiae). J. Appl. Poult. Res. 12 (2003), 27-31

HAVENSTEIN, G.B.; FERKET, P.R.; SCHNEIDER, S.E.; LARSON, B.T.;

Growth, livability and feed conversion of 1957 vs 1991 broilers when fed "typical" 1957 and 1991 broiler diets. Poult. Sci. 73 (1994), 1785-1794

HURWITZ, S.; TALPAZ, H.; BARTOV, I.; PLAVNIK, I.:

Characterization of growth and development of male British United turkeys. Poult. Sci., 70 (1991), 24192424

LAMARE, M.D.; MLADENOV, P.V.:

Modeling somatic growth in the sea urchin Evechinus chloroticus (Echinoidea: Echinometridae). J. Exp. Mar. Biol. Ecol. 243 (2000), 17-43

LAWRENCE, T.L.J.; FOWLER, V.R.:

Growth of Farm Animals. $2^{\text {nd }}$ Ed. CAB International, Wallingford. UK. (2002), pp. 347

LEHMANN, R.:

Comparing the course of growth in animal farm animals. Arch. Tierz., Berlin 20 (1977) 4, 237-248

MARUYAMA, K.; POTTS, W.J.E.; BACON, W.L.; NESTOR, K.E.:

Modeling turkey growth with the relative growth rate. Growth Dev. Aging. 62 (1998) 4, 123-139

MARUYAMA, K.; AKBAR, M.K.; TURK, C.M.:

Growth pattern and carcass development in male ducks selected for growth rate. Br. Poult. Sci. 40 (1999) 2, 233-239.

MATTHES, H.-D.; RUDOLPH, P.E.; HERRENDÖRFER, G.:

Characterization of growth of beef cattle with growth function (In German Language). Arch. Tierz., Dummerstorf 39 (1996) 2, 121-127

MENDEŞ, M.; KARABAYIR, A.; ERSOY, I.E.; ATASOGLU, C.:

Effects of three different lighting programs on live weight change of bronze turkeys under semi-intensive conditions. Arch. Tierz., Dummerstorf 48 (2005) 1, 86-93

PISCART, C. ; DEVIN, S. ; BEISEL, J.N. ; MORETEAU, J.C. :

Growth-related life-history traits of an invasive gammarid species: evaluation with a Laird-Gompertz model. Can. J. Zoot. 81 (2003), 2006-2014

RECHNER, A.C.:

Methods of multivariate analysis. John Wiley \& Sons, New York, USA. (1995)

RICHARDS, F.J.:

A flexible growth function for empirical use. J. Exp. Bot. 10 (1959), 290-300 
SAGER, G.:

Mathematical formulations of height growth of Holstein cattle. Arch. Tierz., Berlin 25 (1982) 3, 185-194 SAS. :

SAS / STAT User's Guide (Version 6, $4^{\text {th }}$ Ed.) SAS Inst. Inc., Cary, NC. (1999)

SALOMON, F.V.; SAGER, G.; AL HALLAK, M.; PINGEL, H.:

Growth specific approximations for 11 body dimensions of fowls. 3. Report : analysis of growth series of ducks. Arch. Geflügelk. 51 (1987), 136-141

SCHULZE, V.; RÖHE, R.; LOOFT, H.; KALM, E.:

Genetic analysis of the course of individual growth and feed intake of group-penned performance tested boars (In German Language). Arch. Tierz., Dummerstorf 44 (2001) 2, 139-156.

SEELAND, G.; RÖBLER, B.; RÖDER, B.:

Analysis of growth of different rabbit breeds with selected growth functions (In German Language). Arch. Tierz., Dummerstorf 39 (1996) 5, 533-544

SZÖKE, S.; KOMLOSI, I.; KOROM, E.; ISPANY, M.; MIHOK, S.:

A statistical analysis of population variability in bronze turkey considering gene conservation. Arch. Tierz., Dummerstorf 47 (2004) 4, 377-385

VON ROSEN, D.:

The growth curve model: a review. Comm. Stat.: Theory and Methods 20 (1991), 2791-2822 ZEIDE, B.:

Analysis of growth equations. For. Sci. 39 (1993) 3, 594-616

Received: 2005-04-21

Accepted: 2005-12-07

Authors addresses

Assist. Prof. Dr. MEHMET MENDEŞ (Corresponding author)

Canakkale Onsekiz Mart University Agriculture Faculty Biometry and Genetic Department, 17020 Canakkale / TURKEY

E-mail: mmendes@comu.edu.tr

Research Assistant. I. ERBIL ERSOY

Canakkale Onsekiz Mart University Agriculture Faculty Department of Animal Science, 17020 Canakkale / TURKEY

E-mail: erbilersoy@comu.edu.tr

Assist.Prof. Dr. SEDAT AKTAN

Süleyman Demirel University, Faculty of Agriculture, Department of Animal Sciences, 32260, Isparta, TURKEY 